\title{
The Size Distribution of US Banks and Credit Unions
}

Goddard, J.A.; Goddard, J.; Liu, H.; McKillop, D.; Wilson, J.O.

\section{International Journal of the Economics of Business}

DOI:

$10.1080 / 13571516.2013 .835970$

Published: 06/02/2014

Peer reviewed version

Cyswllt i'r cyhoeddiad / Link to publication

Dyfyniad o'r fersiwn a gyhoeddwyd / Citation for published version (APA):

Goddard, J. A., Goddard, J., Liu, H., McKillop, D., \& Wilson, J. O. (2014). The Size Distribution of US Banks and Credit Unions. International Journal of the Economics of Business, 21(1), 139156. https://doi.org/10.1080/13571516.2013.835970

\footnotetext{
Hawliau Cyffredinol / General rights

Copyright and moral rights for the publications made accessible in the public portal are retained by the authors and/or other copyright owners and it is a condition of accessing publications that users recognise and abide by the legal requirements associated with these rights.

- Users may download and print one copy of any publication from the public portal for the purpose of private study or research.

- You may not further distribute the material or use it for any profit-making activity or commercial gain

- You may freely distribute the URL identifying the publication in the public portal ?
}

Take down policy

If you believe that this document breaches copyright please contact us providing details, and we will remove access to the work immediately and investigate your claim. 


\title{
The Size Distribution of US Banks and Credit Unions ${ }^{+}$
}

\author{
John Goddard ${ }^{\mathrm{a}}$, Hong Liu ${ }^{\mathrm{b}}$, Donal McKillop ${ }^{\mathrm{c}}$, John O.S. Wilson ${ }^{\mathrm{d}, \mathrm{x}}$
}

\begin{abstract}
This study examines the firm size distribution of US banks and credit unions. A truncated lognormal distribution describes the size distribution, measured using assets data, of a large population of small, community-based commercial banks. The size distribution of a smaller but increasingly dominant cohort of large banks, which operate a high-volume low-cost retail banking model, exhibits power-law behaviour. There is a progressive increase in skewness over time, and Zipf's Law is rejected as a descriptor of the size distribution in the upper tail. By contrast, the asset size distribution of the population of credit unions conforms closely to the lognormal distribution.
\end{abstract}

JEL Classification: G21; L10; L16

Keywords: Firm Size distribution, Zipf's Law, Gibrat's Law, Banks, Credit Unions

$+\quad$ The authors gratefully acknowledge the helpful comments of two anonymous referees on an earlier draft of this paper. The usual disclaimer applies.

Bangor Business School, Bangor University, Bangor, Gwynedd, LL57 2DG, UK. Tel: +44 1248 383221. Email: j.goddard@bangor.ac.uk

Accounting and Finance, Business School, University of Glasgow, Glasgow, G12 8QQ, UK. Tel: +44 141330 6124. Email: hong.liu@glasgow.ac.uk

Queen's University Management School, Queen's University of Belfast, 185 Stranmillis Road, Belfast, BT9 5EE UK.. Tel: +44 289097 4852. Email: dg.mckillop@qub.ac.uk KY16 9SS, UK. Tel: +44 1334 462803. Email: jsw7@st-andrews.ac.uk 


\section{The Size Distribution of US Banks and Credit Unions}

\section{Introduction}

This study examines the empirical size distribution of US banks and credit unions. It is well known that most empirical firm-size distributions are highly skewed. If firm sizes are subject to proportional random growth, consistent with Gibrat's Law so that log sizes follow random walks, a lognormal cross-sectional firm-size distribution emerges over time (Gibrat, 1931; Sutton, 1997). There is, however, extensive evidence that the lognormal provides a poor approximation to empirical firm-size distributions in the upper tail, which typically exhibit greater skewness than is consistent with lognormality. Certain modifications to Gibrat's Law, however, are capable of producing a cross-sectional size distribution that exhibits power-law behaviour. ${ }^{\mathrm{i}} \mathrm{A}$ strand in the empirical literature examines the application of lognormal and power-law distributions to cross-sectional firm-size data (Simon and Bonnini, 1958; Quandt, 1966; Lucas, 1978; Cabral and Mata, 2003).

Pareto (1897) describes the distribution of a collection of $\mathrm{N}$ subjects ranked by size, where the density function, denoted $\mathrm{f}(\mathrm{)}$, obeys a power law in the upper tail:

$$
f(X)=\frac{\alpha}{\Theta}\left(\frac{X}{\Theta}\right)^{-(\alpha+1)} \quad \text { for } X \geq \Theta
$$

where $\mathrm{X}$ is size, $\Theta$ is the size threshold above which the Pareto distribution applies, and $\alpha$ is constant. Zipf's Law describes the special case $\alpha=1$ (Zipf, 1949). Axtell (2001) reports that Zipf's Law provides a close approximation to the entire size distribution of US manufacturing firms. ${ }^{\text {ii }}$

The recent financial crisis has heightened interest in the role of large banks in the financial system. Some recent bank efficiency studies, based on data from the 1990s and 2000s, have challenged the earlier received wisdom, derived mainly from the analysis of 
1980s data, that scale economies were rapidly exhausted beyond relatively modest bank sizes. For example, Hughes and Mester (2011) and Wheelock and Wilson (2012) report evidence of scale economies at all sizes, which cannot be attributed solely to an implicit "too big to fail" (TBTF) subsidy. Across the empirical banking literature as a whole, however, the evidence as to whether large banks operate at lower average costs than their smaller counterparts is rather weak and contradictory (Davies and Tracey, 2012).

Awareness that the failure of one large bank could tip many other banks into default is widely perceived to have contributed to the emergence among depositors and investors of a TBTF mentality: a presumption that the regulator would intervene and bail out a TBTF bank, rather than permit failure. Steps taken by governments in the US, Western Europe and elsewhere at the height of the crisis in 2008 to bail out numerous large banks that would otherwise have become insolvent have heightened concerns over TBTF. Among the consequences is a weakening of market discipline, with little incentive for depositors and investors to monitor risk-taking. Competition is distorted, because the TBTF bank benefits from an implicit safety-net insurance public subsidy (O’Hara and Shaw, 1990; Morgan and Stiroh, 2005; Mishkin, 2006; Schmid and Walter, 2009; Brewer and Jagtiani, 2012).

Historically, geographic and product market regulations have constrained the growth of US banks, and the largest US banks were small by comparison with the largest European and Japanese banks (DeYoung, 2010). Since the 1980s, however, financial deregulation has eased many of the earlier constraints on growth. ${ }^{\text {iii }}$ Consolidation through M\&A (merger and acquisition) reduced the number of commercial banks, from around 14,400 in 1980 to around 6,400 in $2010{ }^{\text {iv }}$ Industry concentration measured, for example, using the ten-firm concentration ratio for the assets of all separately constituted commercial banks (irrespective of ownership), has increased from 0.300 in 1980 to 0.555 in 2010 . It seems likely that many 
of the banks that disappeared were simply too small to compete effectively in a less heavily regulated and more highly competitive banking market.

Despite the increasing dominance of large banks, and their importance for financial stability, to our knowledge only one previous study has examined the statistical characteristics of the firm-size distribution for banks. Janicki and Prescott (2006), henceforth JP, report estimation results obtained by fitting a Pareto distribution to the upper tail of assets, deposits, loans and employees data for US commercial banks and Bank Holding Companies (BHC) at ten- or fifteen-year intervals between 1960 and 2005. Zipf's Law is found to provide a close approximation to the data in all of the years examined except 2005 , for which the upper tail is heavier than is consistent with Zipf's Law.

An important technical limitation of the methodology used by JP is the imposition of an arbitrarily chosen value for the threshold parameter $\Theta$, corresponding to the asset size of the bank ranked 3,000th in the firm-size distribution. A consequence of this limitation is that JP are unable to provide an accurate description of changes in the shape of the firm-size distribution, especially changes in the location of $\Theta$, over time. The present study overcomes this limitation, by applying an estimation method that permits a choice between fitting the lognormal distribution over the entire range of firm sizes, and fitting a combination of a truncated lognormal distribution for smaller firms and a Pareto distribution for firms above the size threshold $\Theta$. In the latter case, the choice of $\Theta$ is determined by the data, and $\Theta$ is permitted to vary over time. It is shown that the true location of $\Theta$ for commercial banks is, in fact, considerably nearer the upper end of the firm size distribution than the arbitrary location assumed by JP; and that the Pareto upper tail describes the size distribution of a correspondingly smaller proportion of the population. Between 1995 and 2010, for example, the proportion of the population of commercial banks represented by the Pareto upper tail fell from $6.2 \%$ (611 banks) to $2.8 \%$ (180 banks). Owing to the highly skewed nature of the firm- 
size distribution, however, these 180 banks accounted for more than $85 \%$ of banking industry assets in 2010.

This study also compares the size distribution of commercial banks with that of (notfor-profit) credit unions. The growth of credit unions is constrained by common-bond restrictions on the groups with which they are permitted to transact, despite moves in recent years towards the easing of several of the restrictions. It is of interest to examine whether the combination of a non-profit orientation and a restrictive regulatory environment generates a similar or differently-shaped firm-size distribution over the long term. The empirical results suggest that the shape of the size distribution does, indeed, differ markedly between commercial banks and credit unions. The size distribution of commercial banks is described by a truncated lognormal distribution and a Pareto distribution in the upper-tail. There is a pronounced trend in the upper-tail shape parameter that reflects an increase in skewness over time. By contrast, the lognormal distribution provides an accurate description of the entire size distribution of credit unions throughout the observation period.

The rest of this study is structured as follows. Section 2 describes the estimation method. Section 3 reports estimation results for the population of US commercial banks for the period 1976-2010. Section 4 reports an application of the same methods to the population of US credit unions over the period 1995-2010. Finally, Section 5 summarizes and concludes.

\section{Estimation Method}

Let $\mathrm{X}_{\mathrm{i}}$ denote the assets of firm $\mathrm{i}$ in a particular year, and let $\mathrm{X}_{\mathrm{i}}=\ln \left(\mathrm{X}_{\mathrm{i}}\right)$. Let $\mathrm{X}_{[\mathrm{i}]}$ denote the value of the i'th observation when the firms are ranked in descending order of asset size, so $\mathrm{X}_{[1]} \geq \mathrm{X}_{[2]} \geq \ldots \geq \mathrm{X}_{[\mathrm{n}]}$, and let $\mathrm{x}_{[\mathrm{i}]}=\ln \left(\mathrm{X}_{[\mathrm{i}]}\right)$. Let $\Theta_{\mathrm{k}}=\mathrm{X}_{[\mathrm{k}]}$ denote some threshold value of $\mathrm{k}$ that is, initially, assumed to be pre-selected, and let $\theta_{\mathrm{k}}=\mathrm{x}_{[\mathrm{k}]}$.

We examine two candidate distributions for $\mathrm{X}_{\mathrm{i}}$ : 
(i) $\quad \mathrm{x}_{\mathrm{i}} \sim \mathrm{N}\left(\mu_{0}, \sigma_{0}^{2}\right)$ for all i

(ii) $\quad \mathrm{x}_{\mathrm{i}} \sim \mathrm{TN}\left(\mu_{\mathrm{k}}, \sigma_{\mathrm{k}}^{2},-\infty, \theta_{\mathrm{k}}\right)$ for $\mathrm{x}_{\mathrm{i}}<\theta_{\mathrm{k}}$, and $\mathrm{X}_{\mathrm{i}} \sim \operatorname{Par}\left(\Theta_{\mathrm{k}}, \alpha_{\mathrm{k}}\right)$ for $\mathrm{X}_{\mathrm{i}} \geq \Theta_{\mathrm{k}}$

In (i), the distribution of $X_{i}$ is lognormal with mean and variance parameters $\mu_{0}$ and $\sigma_{0}^{2}$, for all $\mathrm{i}$. In (ii), the distribution of $\mathrm{X}_{\mathrm{i}}$ is truncated lognormal with mean and variance parameters $\mu_{\mathrm{k}}$ and $\sigma_{\mathrm{k}}^{2}$, and an upper truncation point $\theta_{\mathrm{k}}$, for $\mathrm{X}_{\mathrm{i}}<\Theta_{\mathrm{k}}$; and Pareto with location and shape parameters $\Theta_{k}$ and $\alpha_{k}$, for $X_{i} \geq \Theta_{k}$.

For (i), the maximum likelihood estimators of $\mu_{0}$ and $\sigma_{0}^{2}$ are $\hat{\mu}_{0}=\mathrm{n}^{-1} \sum_{\mathrm{i}=1}^{\mathrm{n}} \mathrm{x}_{\mathrm{i}}$ and $\hat{\sigma}_{0}^{2}=\mathrm{n}^{-1} \sum_{\mathrm{i}=1}^{\mathrm{n}}\left(\mathrm{x}_{\mathrm{i}}-\hat{\mu}_{0}\right)^{2}$. The maximized log-likelihood function is $\ln \left(\mathrm{L}_{0}\right)=$ $\sum_{\mathrm{i}=1}^{\mathrm{n}} \ln \phi\left[\left(\mathrm{x}_{\mathrm{i}}-\hat{\mu}_{0}\right) / \hat{\sigma}_{0}\right]$, where $\phi$ is the standard normal density function.

For (ii), the likelihood function that would be formed over the two segments of the distribution is discontinuous at the truncation point $\theta_{\mathrm{k}}$. Accordingly, we estimate the parameters $\mu_{\mathrm{k}}, \sigma_{\mathrm{k}}^{2}, \mathrm{k}, \Theta_{\mathrm{k}}$ and $\alpha_{\mathrm{k}}$ in two stages.

\section{Stage 1}

Let $\overline{\mathrm{x}}_{\mathrm{k}}=(\mathrm{n}-\mathrm{k})^{-1} \sum_{\mathrm{i}=\mathrm{k}+1}^{\mathrm{n}} \mathrm{x}_{[\mathrm{i}]}$ and $\mathrm{s}_{\mathrm{k}}^{2}=(\mathrm{n}-\mathrm{k}-1)^{-1} \sum_{\mathrm{i}=\mathrm{k}+1}^{\mathrm{n}}\left(\mathrm{x}_{[\mathrm{i}]}-\overline{\mathrm{x}}_{\mathrm{k}}\right)^{2}$ denote the sample mean and sample variance of all $\mathrm{x}_{[\mathrm{i}]}<\theta_{\mathrm{k}}$. For $\mathrm{x}_{\mathrm{i}} \sim \mathrm{TN}\left(\mu_{\mathrm{k}}, \sigma_{\mathrm{k}}^{2},-\infty, \theta_{\mathrm{k}}\right)$ :

$\mathrm{E}\left(\mathrm{x}_{\mathrm{i}}\right)=\mu_{\mathrm{k}}-\phi\left[\left(\theta_{\mathrm{k}}-\mu_{\mathrm{k}}\right) / \sigma_{\mathrm{k}}\right] / \Phi\left[\left(\theta_{\mathrm{k}}-\mu_{\mathrm{k}}\right) / \sigma_{\mathrm{k}}\right]$

$$
\begin{aligned}
\mathrm{V}\left(\mathrm{x}_{\mathrm{i}}\right)=\sigma_{\mathrm{k}}^{2}\left\{1-\left[\left(\theta_{\mathrm{k}}-\mu_{\mathrm{k}}\right) / \sigma_{\mathrm{k}}\right] \phi\left[\left(\theta_{\mathrm{k}}-\mu_{\mathrm{k}}\right) / \sigma_{\mathrm{k}}\right] / \Phi\left[\left(\theta_{\mathrm{k}}-\mu_{\mathrm{k}}\right) / \sigma_{\mathrm{k}}\right]\right\} & \\
& +\sigma_{\mathrm{k}}^{2}\left\{\phi\left[\left(\theta_{\mathrm{k}}-\mu_{\mathrm{k}}\right) / \sigma_{\mathrm{k}}\right] / \Phi\left[\left(\theta_{\mathrm{k}}-\mu_{\mathrm{k}}\right) / \sigma_{\mathrm{k}}\right]\right\}^{2}
\end{aligned}
$$


where $\Phi$ is the standard normal distribution function. The estimates $\hat{\mu}_{\mathrm{k}}$ and $\hat{\sigma}_{\mathrm{k}}^{2}$ are obtained by selecting the pair of values for $\mu_{\mathrm{k}}$ and $\sigma_{\mathrm{k}}^{2}$ that minimise the distance function $\mathrm{D}=\left[\mathrm{E}\left(\mathrm{x}_{\mathrm{i}}\right)-\overline{\mathrm{y}}_{\mathrm{k}}\right]^{2}+\left[\mathrm{V}\left(\mathrm{x}_{\mathrm{i}}\right)-\mathrm{s}_{\mathrm{k}}^{2}\right]^{2}$

\section{Stage 2}

Estimation of $\alpha_{k}$ proceeds by applying maximum likelihood to the observations $X_{[1]}, \ldots, X_{[k]}$, which are assumed to follow the Pareto distribution. The log-likelihood function takes the form $\sum_{\mathrm{i}=1}^{\mathrm{k}} \ln \left[\left(\alpha_{\mathrm{k}} / \Theta_{\mathrm{k}}\right)\left(\mathrm{X}_{[\mathrm{i}]} / \Theta_{\mathrm{k}}\right)^{-\left(\alpha_{\mathrm{k}}+1\right)}\right]$. Zipf's Law describes the special case $\alpha_{\mathrm{k}}=1$, for which Stage 2 (the estimation of $\alpha_{k}$ ) is not required. A grid-search is used to identify the value of $k$ that maximises the pseudo-log-likelihood function, constructed as follows:

$$
\begin{aligned}
\ln \left(\mathrm{L}_{\mathrm{k}}\right)=\sum_{\mathrm{i}=\mathrm{k}+1}^{\mathrm{n}} \ln & \left.\operatorname{l} \phi\left[\left(\mathrm{x}_{[\mathrm{i}]}-\hat{\mu}_{\mathrm{k}}\right) / \hat{\sigma}_{\mathrm{k}}\right]\right\} \\
& +\sum_{\mathrm{i}=1}^{\mathrm{k}} \ln \left\{\left(\hat{\alpha}_{\mathrm{k}} / \Theta_{\mathrm{k}}\right)\left(\mathrm{X}_{[\mathrm{i}]} / \Theta_{\mathrm{k}}\right)^{-\left(\hat{\alpha}_{\mathrm{k}}+1\right)} \mathrm{X}_{[\mathrm{i}]}\left\{1-\Phi\left[\left(\mathrm{x}_{[\mathrm{i}]}-\hat{\mu}_{\mathrm{k}}\right) / \hat{\sigma}_{\mathrm{k}}\right]\right\}\right\}
\end{aligned}
$$

In the special case described by Zipf's Law, $\hat{\alpha}_{\mathrm{k}}$ is replaced by one in [4].

By convention, the rank-size relationship is commonly depicted using a plot of log rank against log size. If asset sizes follow a Pareto distribution in the upper tail, the log rank$\log$ size relationship is linear over the relevant range of asset-size values, with a slope of $-\alpha_{k}$. This follows from

$$
\mathrm{j}=\mathrm{k} \int_{\mathrm{x}_{[j]}}^{\infty} \mathrm{f}(\mathrm{z}) \mathrm{dz}=\mathrm{k} \Theta_{\mathrm{k}}^{\alpha_{\mathrm{k}}} X_{[\mathrm{j}]}^{-\alpha_{\mathrm{k}}}
$$

where $\mathrm{j} \leq \mathrm{k}$ is the continuous analogue of the (discrete) rank, and $\mathrm{f}$ is the density function of the Pareto distribution. Applying a log transformation yields

$\ln (j)=\ln (k)+\alpha_{k} \theta_{k}-\alpha_{k} x_{[j]}$

In the special case described by Zipf's Law, the slope of the log rank-log size plot is -1 . 


\section{The Size Distribution of US Banks}

The data source for the empirical analysis of the assets size distribution of US commercial banks is Reports on Condition and Income (Call Reports) provided by the Federal Financial Institution Examination Council. Data on savings banks, savings and loan associations, investment banks, mutual banks and credit-card banks are excluded. Table 1 reports descriptive statistics based on the fourth-quarter reports at five-year intervals from 1980 to 2010. Panels A and B report an analysis in which commercial banks are the units of observation, disregarding ownership. Accordingly, in the 'all commercial banks' population, commercial banks that are constituents of the same BHC are treated as separate observations. Most previous studies of the evolution of the US banking industry focus on banks, rather than BHC (Berger et al., 1995; Jones and Critchfield, 2005). In part this is because many price and non-price decisions are taken at bank level. Regulation concerned with competition and antitrust issues also tends to focus on the bank, and not the BHC. ${ }^{\mathrm{v}}$

Table 1 Panel A reports summary descriptive statistics for the firm-size distribution based on balance-sheet assets. The data are yearly for the period 1976-2010, but to conserve space Table 1, and subsequent tables, report results only at five-year intervals during 19802010. The number of commercial banks fell steadily throughout this period, owing primarily to M\&A. Industry concentration fell slightly during the 1980 s, but increased during the 1990 s and 2000s. These trends are apparent in the five-, ten- and twenty-firm concentration ratios, and the Herfindahl index.

The results reported in Panel A based on balance-sheet assets do not fully reflect the lending capacity of banks or BHC that enter into commitments that do not appear on their balance sheets, such as guaranteed lines of credit upon which borrowers can draw at their discretion. Before 1990, most US banks did not report off balance sheet (OBS) commitments in their company accounts; but subsequently these commitments have been reported widely. 
In order to render the OBS data compatible with the balance-sheet assets data, individual OBS items are converted into credit equivalents, which are then added to balance-sheet assets to create a total size measure for each bank that reflects its total lending commitments. ${ }^{\mathrm{vi}}$ Table 1 Panel B reports summary descriptive statistics for the firm-size distribution during 1990-2010, based on the sum of balance-sheet assets and OBS credit equivalents. The inclusion of the latter increases the measured average bank size by around 12\% in 1990, and 77\% in 2010. The concentration measures and Herfindahl index are all substantially larger when OBS commitments are included, indicating that the latter are concentrated disproportionately among the larger banks.

For purposes of comparison with the JP study, Table 1 Panels C and D report an analysis in which 'ownership groups' are the units of observation. The data for any banks that are constituents of the same $\mathrm{BHC}$ are aggregated to form a single observation, while the data for independently-owned commercial banks are retained as separate observations. ${ }^{\text {vii }}$ BHC accounts report data that reflects the summation of both banking and non-banking business. Since the 1990s, and especially since the passing of the Gramm Leach Bliley Act in 1999, the importance of non-banking business to BHC has increased, especially for larger entities (Avraham et al. 2012; Copeland, 2012). In 2008, investment banks such as Goldman Sachs and Morgan Stanley (which hold the bulk of their assets outside banking subsidiaries) converted to BHC status. In order to avoid the inclusion of non-banking assets, bank subsidiaries only are included in the construction of aggregated BHC data. ${ }^{\text {viii }}$ Panel C reports summary statistics for the firm-size distribution during 1980-2010 based on BHC balancesheet assets. Panel D reports the equivalent results for 1990-2010 obtained by adding OBS credit equivalents to balance-sheet assets.

Table 2 reports the empirical analysis of patterns in the assets size distribution of US banks. As before, Panel A reports the results for 'all commercial banks' based on balance- 
sheet assets (1980-2010), and Panel B reports the results for 'all commercial banks' based on the sum of assets and OBS credit equivalents (1990-2010 only). Panels C and D report the equivalent results for the 'ownership groups' definition. Figures 1 and 2 present summary yearly results for the entire observation period, in the form of plots of the estimated k and $\alpha_{k}$ based on balance-sheet assets. The comparison between the two candidate distributions, (i) lognormal and (ii) truncated lognormal with Pareto upper tail, favours (ii) in every year reported in Table 3, and in all of the intermediate years that are not reported. A KolmogorovSmirnov test rejects the null hypothesis of lognormality for the entire size distribution in every case. $^{\text {ix }}$

For the 'all commercial banks' population and balance-sheet assets, Table 2 Panel A indicates that the percentile of the asset size distribution at which the estimated threshold parameter $\Theta_{\mathrm{k}}$ is located varies between a minimum value of 95.5 and a maximum of 96.8 between 1976 and 1990, when there is no discernible trend. Between 1991 and 1995 this percentile drops to 93.8; but from 1996 onwards there is a steady trend in the reverse direction. The percentile of the asset size distribution at which $\Theta_{\mathrm{k}}$ is located attains its highest value of 97.2 in 2010 (see Figure 1). Despite the decrease in the number of banks located in the upper tail, their share of total assets, measured by the k-firm concentration ratio $\mathrm{CR}_{\mathrm{k}}$, increases steadily over the observation period, from 0.719 in 1980 to 0.856 in 2010 . While the Pareto upper tail comprises only $2.8 \%$ of all commercial banks operating in 2010, these banks account for more than $85 \%$ of total banking-sector assets.

The estimated upper-tail shape parameter $\hat{\alpha}_{k}$ is below one, but not significantly different from one, for 1976 and 1977, the first two years in the data set. For every subsequent year, however, the estimated $\alpha_{k}$ is significantly below one; and there is a downward trend that is most pronounced during the 1980s and early 1990s. Accordingly, Zipf's Law is rejected as a descriptor of the size distribution in the upper tail, in favour of a 
Pareto power-law distribution with a heavier upper tail than would be expected under Zipf's Law. Relative to the rest of the distribution, the weight of the upper tail has increased since the mid-1990s, reflected in the downward trend in the estimated $\alpha_{k}$. The results based on the sum of balance-sheet assets and OBS credit equivalents, reported in Table 2 Panel B, indicate a similar downward trend in the estimated $\alpha_{k}$ during the period 1990-2010.

For the 'ownership groups' population and balance-sheet assets, a trend in the rank at which the estimated threshold $\Theta_{\mathrm{k}}$ is located is apparent from the mid-1980s onwards in Table 2 Panel C. Over the entire period 1976-2010, the percentile of the asset size distribution at which the threshold value of $\mathrm{k}$ is located attains a minimum value of 94.4 in 1983 and a minimum of 97.6 in 2008. The estimated upper-tail shape parameter $\alpha_{\mathrm{k}}$ is significantly below one in every year. Again Zipf's Law is rejected as a descriptor of the size distribution in the upper tail of the 'ownership groups' population, in favour of a Pareto power-law distribution with a heavier tail than is required for conformity with Zipf's Law. As before the results based on the sum of balance-sheet assets and OBS credit equivalents, reported in Table 2 Panel D, indicate a similar pattern for the period 1990-2010.

Figure 3 reports scatter plots, on a logarithmic scale, of the relationship between rank and asset size, for the 'all commercial banks' population in 1980, 1990, 2000 and 2010. In each case, the theoretical rank-size plot for a lognormal distribution with mean and variance corresponding to the sample estimates over the entire sample is located (thin dotted line). The equivalent plots for the upper tail, assuming banks larger than the estimated size threshold $\mathrm{k}$ follow the Pareto distribution in accordance with either Zipf's Law, or the fitted shape parameter $\alpha_{k}$, are also located (thick dotted line, and continuous line, respectively). Accordingly, the continuous line represents the maximum likelihood estimate of the Pareto upper tail, while the thick dotted line represents an upper tail with a shape parameter in accordance with Zipf's Law. ${ }^{\mathrm{x}}$ The maximum likelihood estimates provide a close, if less than 
perfect, representation of the upper tail, with a slight tendency to overstate the number of firms at the top end of the distribution (more so in 1980, 1990 and 2000 than in 2010).

Table 3 reports summary results for three alternative firm size measures: loans, deposits and employees. ${ }^{\mathrm{xi}}$ As before, in every estimation the choice between the two candidate distributions favours (ii) truncated lognormal with Pareto upper tail. For each size measure and for each of the two population definitions, the threshold value of $\mathrm{k}$ and the estimated upper-tail shape parameter $\alpha_{\mathrm{k}}$ are reported. The results are similar to those for the assets size measure. In all cases $\mathrm{k}$ diminishes over the entire observation period, and the estimated $\alpha_{\mathrm{k}}$ shows a tendency to decrease in magnitude. ${ }^{\text {xii }}$

The notion that the commercial banks population divides into two discrete categories defined by scale is consistent with the characterization of the evolution of the US commercial banking industry described by DeYoung, Hunter and Udell (2004), henceforth DHU. Prior to the 1980s, the industry was dominated by a large number of small, community-based banks, offering differentiated or customized loan products and a highly personalized service, and operating at relatively high unit cost. Subsequently, deregulation and technological change created new strategic opportunities for growth that were realized initially by within-market M\&A, and later by larger-scale M\&A that greatly extended the market reach of the merged entities. ${ }^{\text {xiii }}$ Those banks that grew most aggressively came to bear less resemblance to community banks, by adjusting to a high-volume low-cost retail banking model reliant on scale economies, in which automated production and distribution processes deliver standardized products and services at low unit cost. A consequence has been the emergence of "... a strategic wedge between the large and growing banks on the one hand and the smaller community banks on the other" (op cit, p110). Although many community banks have also grown, they continue to operate under a traditional high unit-cost and high value-added retail banking model. 
A rule-of-thumb used by DHU defines community banks as those with assets below around USD 1 billion (2001 prices). This figure corresponds quite closely to the threshold asset size value of USD 1.2 billion for the year 2000 that is quoted in Table 2, below which the fitted size distribution is truncated lognormal and above which Pareto. According to Table 2 , the cut-off asset size value that separates the smaller community banks from the larger ones that have outgrown community status increased to around USD 2 billion in 2005, and USD 3 billion in 2010 (all values in current prices). The number of banks in the upper tail fell from 325 (96.1 percentile of the assets-size distribution) in 2000 to 267 (96.4 percentile) in 2005, and 180 (97.2 percentile) in 2010.

\section{The Size Distribution of US Credit Unions}

Credit unions are cooperative not-for-profit financial organizations under mutual ownership that provide basic banking services to their members. A credit union's worth is based on book value rather than market value. Accordingly, credit unions are not subject to market-driven expectations for growth and earnings performance. Credit unions are subject to a common bond, which defines the groups with which each credit union is permitted to transact. The common bond might be defined by residence in a particular geographic area, employment in a particular company or industry, or religious or some other affiliation. Deregulation has, to a limited extent, eased the constraint on the growth of individual credit unions imposed by the common bond. The Credit Union Membership Access Act of 1998 permitted federally-chartered credit unions to operate with a multiple common bond, or to transact with any resident of a geographical area defined as a 'community'. Neither banks nor credit unions face restrictions on the prices they charge for specific products. Credit unions, however, face some restrictions on their volumes of small-business lending, while banks are subject to limits on lending concentration. In common with commercial banking, the US 
credit union industry has experienced significant consolidation through $M \& A$ in recent decades. ${ }^{\text {xiv }}$

The data source for the empirical analysis of the assets size distribution of US credit unions is the '5300 Call Reports', published by the National Credit Union Association (NCUA). Table 4 reports an analysis of patterns in the assets size distribution of US credit unions, based on the December reports at five-year intervals within the period 1995-2010. A steady decline in the number of credit unions, which has been underway since the 1970s, has seen numbers fall from around 11,700 in 1995 to around 7,300 in 2010. Consistent with the pattern for US banks, industry concentration, measured by the five-, ten- and twenty-firm concentration ratios and the Herfindahl index, has increased steadily throughout this period; but concentration remains considerably lower than it is for commercial banks.

The comparison between the two candidate distributions, (i) lognormal and (ii) truncated lognormal with Pareto upper-tail, favours (i) in each of the years reported in Table 1 , and in all of the intermediate years that are not reported. For most years, the estimation procedure fails to identify a value of $\mathrm{k}$ for which the maximised value of the pseudo-loglikelihood function in (ii) is larger than the corresponding value in (i); and for those years for which such a value of $\mathrm{k}$ is identified, the difference between the maximized value of the pseudo-log-likelihood function for (i) and (ii) is marginal and not statistically significant on any conventional criterion. A Kolmogorov-Smirnov test fails to reject the null hypothesis of lognormality at the 0.01 level for all years within the observation period; although there are five rejections at the 0.05 level (for years 2003-2006 inclusive, and 2010). Figure 4 shows the scatter plot of the relationship between log rank and log asset size for 2010 . Only three credit unions, each with assets of more than USD 10 billion, were larger than would be expected if the entire asset-size distribution were lognormal in $2010 .{ }^{\mathrm{xv}}$ Overall the lognormal distribution appears to provide a satisfactory, but not a perfect, representation of the asset size distribution 
of US credit unions. There is no evidence of conformity with a power law in the upper tail of this firm-size distribution.

\section{Conclusion}

This study examines the application of lognormal and power-law distributions to cross-sectional firm-size data for US commercial banks and credit unions. For banks, the firm size distribution is accurately described by a truncated lognormal distribution with a Pareto or power-law distribution in the upper tail. Zipf's Law is rejected as a descriptor of the firm size distribution in the upper tail for all except the first two years of a 1976-2010 observation period. A trend in the upper-tail shape parameter reflects a progressive increase in skewness over time. In 2010, the Pareto upper tail contains only $2.8 \%$ of all commercial banks, but these banks account for $85 \%$ of total banking-sector assets.

Deregulation and financial liberalization has eliminated many of the constraints on the growth of US banks that were effective prior to the 1990s. The question as to whether the existence of very large banks is justified on efficiency grounds, with economies of scale yielding average cost savings at the upper end of the firm-size distribution, remains largely unresolved in the empirical banking literature. The suggestion that governments would always bail out "too big to fail" (TBTF) large banks for fear of a contagion effect that could precipitate systemic failure, seemingly more than amply justified by events at the height of the financial crisis at the end of the 2000s, has raised concerns that large banks are subject to inadequate competitive or market discipline. The descriptive form of evidence presented in this paper does not allow us to resolve these crucial issues. However, a descriptive analysis demonstrating that the commercial banks population divides into two distinct categories defined by scale is suggestive and consistent with a characterization of the US commercial banking industry that distinguishes between a large but steadily shrinking population of small 
competitive community-based banks, and a smaller but increasingly dominant group of large banks operating in an environment in which the intensity of competition is moderated by the existence of an implicit TBTF public subsidy.

By contrast, the lognormal distribution describes accurately the entire firm-size distribution of credit unions throughout most of a 1995-2010 observation period, when there is no evidence of power-law behaviour in the upper tail, despite some indications of deterioration in the goodness-of-fit for the lognormal distribution during the second half of this period. Overall the extent of departure from lognormality in the entire credit union firmsize distribution appears rather modest. We conjecture that the combination of a non-profit orientation and a more restrictive regulatory environment accounts for the evolution of a firm-size distribution for all credit unions that is similar to that of the smaller commercial banks, but markedly different to that of the larger banks at the upper end of the size distribution. 


\section{Endnotes}

${ }^{\mathrm{i}}$ These include: proportional growth subject to a reflecting lower barrier (a minimum size threshold beneath which no firm can fall); and proportional growth with deaths at a rate that is inversely proportional to size, and births at a constant size (Gabaix, 2009).

${ }^{\text {ii }}$ See also Stanley et al. (1995) and Growiec et al. (2008). For empirical evidence on the size distribution of cities, regions and countries, see Gabaix (1999a,b); Eeckhout (2004); Rose (2006); and Luttmer (2007).

iii For example, the McFadden Act of 1927, which prohibited interstate branch banking, was repealed by the Riegle-Neal Interstate Banking and Branching Efficiency Act of 1994; and the Glass-Steagall Act of 1933, which prohibited commercial banks from transacting other financial services including investment banking and insurance, was repealed by the Gramm-Leach-Bliley Financial Services Modernization Act of 1999. Berger et al. (1995) and DeYoung (2010) describe the evolution of the US banking industry.

iv According to DeYoung (2010), around 350 commercial banks were acquired each year during the1980s, around 500 each year during the 1990s, and around 300 each year during the first half of the 2000s. More than 10,000 bank charters were terminated owing to acquisitions (excluding acquisitions enforced by the Federal Deposit Insurance Corporation owing to severe financial distress) between 1980 and 2005, and acquisitions accounted for more than $80 \%$ of all bank charters that terminated during this period.

${ }^{\mathrm{A}}$ A number of publications routinely monitor changes in the size distribution and performance of commercial banks. For example, the FDIC Quarterly Banking Profile provides a summary of financial results for all FDICinsured commercial banks. The Federal Reserve annual publication Profits and Balance Sheet Developments at US Commercial Banks examines banks, and not BHC. Several recent analyses of the effects of the financial crisis on industry structure focus upon the bank and not the BHC (see, for example, Wheelock, 2011). In antitrust cases, policy makers concerned with issues of product and geographic market definition normally consider banks, and not BHCs, to be the appropriate unit of analysis (Gilbert and Zaretsky, 2003).

${ }^{\text {vi }}$ See JP, p312-4. The credit equivalent is a weighted sum of the following OBS items: financial standby letters of credit (weighting $=1.00$ ); performance and standby letters of credit $(0.50)$; commercial standby letters of credit (0.25); risk participations in bankers' acceptances (1.00); securities lent (1.00); retained recourse on small business obligations (1.00); recourse and direct credit substitutes (1.00); other financial assets sold with recourse (1.00); other OBS liabilities (1.00); and unused loan commitments with maturity greater than one year (0.50). Items below the line are usually recorded in notes to the accounts, in supervisory reports, within banks' internal reporting systems, or in some cases not at all. Credit unions typically do not report OBS items.

vii Commercial banks' call reports include a variable which reports (if applicable) the parent BHC code number.

viii Banks that form part of a BHC are subject to bank supervision and regulation. For example, they raise insured deposits, are subject to risk-based capital regulation and prompt corrective action, and have access to lender of last resort facilities via the Federal Reserve discount window.

ix The maximised value of the pseudo-log-likelihood function (not reported in Table 1) for (ii) is substantially larger than the corresponding value for (i) in every case.

${ }^{x}$ In Figure 3, both the maximum likelihood estimate of the Pareto upper tail, and the Zipf's Law upper tail, commence from the maximum likelihood estimate of the cut-off threshold.

${ }^{x i}$ To avoid a proliferation of similar results, for the loans size measure Table 3 only reports the results without the addition of OBS credit equivalents.

xii The finding that the upper tail of the log size distribution can be represented by a Pareto distribution reflects skewness and kurtosis coefficients for the log size distribution that are persistently higher than the values (of zero and three respectively) associated with the normal distribution. This approach, however, leaves open the possibility that the entire log size distribution could be represented by some other probability distribution that allows for excess kurtosis. The Student-t distribution allows flexibility in modelling excess kurtosis through variation in the degrees of freedom parameter. Experimentation with use of the Student-t distribution as an alternative to the normal distribution produced similar results for all four log size measures. As before, the formulation representing the upper tail of the log size population using the Pareto distribution and the rest of the 
population using a truncated Student-t distribution was preferred to the formulation representing the entire population using a Student $\mathrm{t}$-distribution in every case. However, the threshold values of $\mathrm{k}$ that locate the switch between the truncated Student-t and Pareto distributions were persistently smaller than the corresponding threshold values obtained using the normal and Pareto distributions, as reported in Tables 2 and 3. This pattern seems plausible: the Student-t distribution describes accurately a somewhat larger proportion of the upper tail than the normal distribution; but neither of these distributions adequately represents the upper tail in its entirety.

xiii The Gramm-Leach-Bliley Act in 1999 removed many restrictions previously imposed on the activities of banks.

${ }^{\text {xiv }}$ Walter (2006) and Goddard et al. (2009) describe the evolution of the US credit union sector. Wheelock and Wilson (2011) present evidence that credit unions are, on average, too small to benefit from economies of scale.

${ }^{\mathrm{xv}}$ The largest credit union, Navy Federal with assets of USD 44.2 billion in 2010, would have ranked 36th in the distribution of commercial banks by asset size in the same year. 


\section{References}

Avraham, Dafna, Patricia Selvaggi, and James Vickery. (2012) "A structural view of US bank holding companies." Federal Reserve Bank of New York Economic Policy Review, 18, pp. 65-81.

Axtell, Robert L. (2001) “Zipf Distribution of U.S. Firm Sizes.” Science, 293, pp. 18181820.

Berger, Allen N., Anil K. Kashyap, and Joseph M. Scalise, (1995). "The Transformation of the US Banking Industry: What a Long Strange Trip It's Been." Brookings Papers on Economic Activity, 2, pp. 54-219.

Brewer, Elijah and Julapa A. Jagtiani. (2012) How much did banks pay to become too-big-tofail and to become systemically important? Journal of Financial Services Research (forthcoming).

Cabral, Luis M.B., and Mata Jose, (2003) "On the Evolution of the Firm Size Distribution: Facts and Theory.” American Economic Review, 93, pp. 1075-1090.

Copeland, Adam. (2012) "Evolution and heterogeneity among larger bank holding companies: 1994 to 2010." Federal Reserve Bank of New York Economic Policy Review, July, 18, pp. 83-92.

Davies, Richard and Belinda Tracey (2012) "Too big to be efficient? The impact of implicit funding subsidies on scale economies in banking." Bank of England Working Paper.

DeYoung, Robert, William C. Hunter, and Gregory F. Udell, (2004) "The Past, Present and Probable Future for Community Banks", Journal of Financial Services Research, 24, pp. 85133.

DeYoung, Robert, (2010) Banking in the United States, in Berger, Allen N., Philip Molyneux, and John O.S. Wilson (eds.) Oxford Handbook of Banking. Oxford: Oxford University Press.

Eeckhout, Jan, (2004) “Gibrat's Law for (All) Cities.” American Economic Review, 94, pp. $1429-1451$.

Gabaix, Xavier, (1999a) "Zipf's Law: An Explanation." Quarterly Journal of Economics, 114, pp. 739-767.

Gabaix, Xavier, (1999b) "Zipf's Law and the Growth of Cities." American Economic Review, Papers and Proceedings, 114, pp. 129-132.

Gabaix, Xavier, (2009) "Power Laws in Economics and Finance." Annual Reviews in Economics, 1, pp. 255-294.

Gibrat, Robert, (1931) Les Inegalities Economiques, Paris: Sirey.

Gilbert, Alton, and Adam M. Zaretsky, (2003) "Banking Antitrust: Are the Assumptions Still Valid?” Federal Reserve Bank of St. Louis Review, 85, pp. 29-52. 
Goddard, John, Donal G. McKillop, and John O.S. Wilson, (2009) "Which Credit Unions Are Acquired?” Journal of Financial Services Research, 36, pp. 231-252.

Growiec, Jakub, Fabio Pammolli, Massimo Riccaboni, and Eugene, H. Stanley, (2008) "On the Size Distribution of Business Firms.” Economics Letters, 98, pp. 207-212.

Hughes, Joseph, and Loretta J. Mester, (2011) "Who Said Large Banks Don't Experience Scale Economies? Evidence from a Risk-Return-Driven Cost Function." Federal Reserve Bank of Philadelphia Working Paper No. 11-27

Janicki, Hubert P., and Edward C. Prescott, (2006) "Changes in the size distribution of U.S. banks: 1960-2005." Federal Reserve Bank of Richmond Economic Quarterly, 92, pp. 291316.

Jones, K.D., and T.S. Critchfield, (2005) "Consolidation in the US banking industry: is the long, strange trip about to end?" Federal Deposit Insurance Corporation Banking Review, 17 , pp. 30-61.

Lucas Jr, Robert E., (1978) "On the Size Distribution of Business Firms." Bell Journal of Economics, 9, pp. 508-523.

Luttmer, Erzo G.J. (2007) "Selection, Growth, and the Size Distribution of Firms." Quarterly Journal of Economics, 122, pp. 1103-1144.

Mishkin, Frederic.S., (2006). "How Big a Problem is Too Big To Fail?" Journal of Economic Literature 44, pp. 988-1004.

Morgan, Donald P., and Kevin J. Stiroh, (2005) "Too Big to Fail after all these Years." Federal Reserve Bank of New York, Staff Report No. 220, September.

O'Hara, Maureen, and Wayne Shaw, (1990) "Deposit Insurance and Wealth Effects: The Value of Being 'Too Big to Fail'.” Journal of Finance, 45, pp.1587-1600.

Pareto, Vilfredo. (1897) Cours d'Economie Politique 2, F. Pichou, Paris.

Quandt, Richard E. (1966) “On the Size Distribution of Firms.” American Economic Review, 56, pp.416-32.

Rose, Andrew K. (2006) "Cities and Countries." Journal of Money, Credit, and Banking, 38, pp.2225-2245.

Schmid, Markus. M. and Ingo Walter. (2009). "Do Financial Conglomerates Create or Destroy Economic Value?” Journal of Financial Intermediation, 18, pp.193-216.

Simon, Herbert A., and Charles P. Bonini, (1958) "The Size Distribution of Business Firms." American Economic Review, 48, pp.607-17. 
Stanley, Michael H.R., Sergey V. Buldyrev, Shlomo Havlin, Rosairo N. Mantegna, Michael A. Salinger, and Harry E. Stanley, (1995) "Zipf Plots and the Size Distribution of Firms." Economics Letters, 49, pp.453-457.

Sutton, John, (1997) “Gibrat's Legacy.” Journal of Economic Literature, 35, pp.40-59.

Walter, John R. (2006) "Not Your Father's Credit Union." Federal Reserve Bank of Richmond, Economic Quarterly, 92, pp.353-377.

Wheelock, David. C. (2011) "Banking Industry Consolidation and Market Structure: Impact of the Financial Crisis and Recession", Federal Reserve Bank of St. Louis Review, 93, pp. 419-438.

Wheelock, David C. and Paul W. Wilson, (2011) “Are Credit Unions Too Small?” Review of Economics and Statistics, 93, pp.1343-1359.

Wheelock, David C. and Paul W. Wilson, (2012) "Do Large Banks have Lower Costs? New Estimates of Returns to Scale for US Banks." Journal of Money, Credit and Banking, 44, pp.174-199.

Zipf, George K. (1949) The Principle of Least Effort. New York: Hafner. 
Table $1 \quad$ Descriptive statistics: Commercial banks, assets size measure

Asset size distribution

Log asset size distribution

Year No. Mean $\mathrm{CR}_{5} \quad \mathrm{CR}_{10} \quad \mathrm{CR}_{20}$ HHI Mean S.D. Skew. Kurt.

A. All commercial banks

$\begin{array}{rrrrrrrrrrr}1980 & 14411 & 301527 & 0.210 & 0.300 & 0.382 & 125.6 & 11.085 & 1.190 & 1.057 & 6.025 \\ 1985 & 14332 & 345588 & 0.166 & 0.245 & 0.318 & 85.7 & 11.211 & 1.219 & 1.115 & 6.038 \\ 1990 & 12281 & 427828 & 0.135 & 0.210 & 0.282 & 67.8 & 11.345 & 1.261 & 1.213 & 6.114 \\ 1995 & 9907 & 598096 & 0.180 & 0.250 & 0.334 & 96.4 & 11.525 & 1.295 & 1.279 & 6.350 \\ 2000 & 8251 & 957021 & 0.282 & 0.373 & 0.477 & 223.9 & 11.678 & 1.317 & 1.302 & 6.919 \\ 2005 & 7469 & 1354382 & 0.407 & 0.486 & 0.569 & 406.6 & 11.891 & 1.340 & 1.183 & 6.531 \\ 2010 & 6480 & 1851634 & 0.473 & 0.555 & 0.664 & 552.5 & 12.034 & 1.313 & 1.275 & 7.328\end{array}$

B. All commercial banks - including off balance sheet items

$\begin{array}{rrrrrrrrrrr}1990 & 12281 & 480450 & 0.154 & 0.241 & 0.321 & 84.7 & 11.354 & 1.272 & 1.254 & 6.335 \\ 1995 & 9907 & 684239 & 0.199 & 0.282 & 0.372 & 116.3 & 11.538 & 1.309 & 1.323 & 6.579 \\ 2000 & 8251 & 1163547 & 0.308 & 0.420 & 0.540 & 260.4 & 11.692 & 1.332 & 1.356 & 7.253 \\ 2005 & 7469 & 2133831 & 0.504 & 0.626 & 0.701 & 706.4 & 11.913 & 1.361 & 1.266 & 7.116 \\ 2010 & 6480 & 3271054 & 0.629 & 0.723 & 0.796 & 1102.2 & 12.052 & 1.329 & 1.366 & 8.084\end{array}$

C. Ownership groups: BHC and independent commercial banks

$\begin{array}{rrrrrrrrrrr}1980 & 12394 & 456013 & 0.212 & 0.306 & 0.400 & 133.5 & 11.021 & 1.222 & 1.307 & 6.857 \\ 1985 & 11136 & 444770 & 0.181 & 0.269 & 0.362 & 110.3 & 11.150 & 1.244 & 1.400 & 7.398 \\ 1990 & 9372 & 560622 & 0.162 & 0.255 & 0.381 & 110.3 & 11.279 & 1.264 & 1.460 & 7.605 \\ 1995 & 7662 & 773340 & 0.228 & 0.344 & 0.482 & 169.1 & 11.465 & 1.271 & 1.448 & 7.882 \\ 2000 & 6698 & 1178917 & 0.361 & 0.473 & 0.584 & 337.2 & 11.695 & 1.321 & 1.334 & 7.292 \\ 2005 & 6347 & 1593805 & 0.438 & 0.526 & 0.625 & 473.7 & 11.920 & 1.357 & 1.204 & 6.690 \\ 2010 & 5800 & 2068722 & 0.519 & 0.603 & 0.699 & 662.1 & 12.083 & 1.325 & 1.236 & 7.186\end{array}$

D. Ownership groups: BHC and independent commercial banks - including OBS items

$\begin{array}{rrrrrrrrrrr}1990 & 9372 & 629580 & 0.179 & 0.284 & 0.416 & 128.0 & 11.286 & 1.273 & 1.499 & 7.854 \\ 1995 & 7662 & 884725 & 0.245 & 0.369 & 0.515 & 191.3 & 11.475 & 1.281 & 1.491 & 8.157 \\ 2000 & 6698 & 1433327 & 0.381 & 0.511 & 0.635 & 394.0 & 11.708 & 1.334 & 1.387 & 7.649 \\ 2005 & 6347 & 2511042 & 0.522 & 0.647 & 0.741 & 763.3 & 11.941 & 1.378 & 1.291 & 7.315 \\ 2010 & 5800 & 3654557 & 0.655 & 0.750 & 0.821 & 1191.9 & 12.100 & 1.341 & 1.331 & 7.972\end{array}$

Notes to Table 1

Results reported in Panels A and C are for balance-sheet assets. Results reported in Panels B and D are for the sum of balance-sheet assets and OBS credit equivalents, calculated in accordance with the method described by Janicki and Prescott (2006, pp 312-4).

Asset size is measured in USD thousands, 2010 prices, conversion using IMF US GDP deflator.

$\mathrm{CR}_{5}, \mathrm{CR}_{10}, \mathrm{CR}_{20}$ are the five-, ten- and twenty-firm concentration ratios, respectively. $\mathrm{HHI}$ is the Herfindahl index. 
Table 2 Estimation results: Commercial banks, assets size measure

\begin{tabular}{|c|c|c|c|c|c|c|c|c|c|}
\hline \multirow{2}{*}{\multicolumn{3}{|c|}{$\begin{array}{l}\text { k (value, percentil } \\
\text { A. All commercial banks }\end{array}$}} & $\mu_{\mathrm{k}}$ & $\sigma_{\mathrm{k}}$ & $\Theta_{\mathrm{k}}$ & $\alpha_{k}$ & $s\left(\alpha_{k}\right)$ & $\mathrm{CR}_{\mathrm{k}}$ & K-S \\
\hline & & & \\
\hline 1980 & 609 & 95.8 & 10.938 & 0.957 & 609223 & 0.898 & 0.036 & 0.719 & $0.059^{* *}$ \\
\hline 1985 & 605 & 95.8 & 11.058 & 0.969 & 752914 & 0.841 & 0.034 & 0.719 & $0.064^{* * *}$ \\
\hline 1990 & 520 & 95.8 & 11.182 & 0.988 & 939823 & 0.767 & 0.034 & 0.735 & $0.073^{* * *}$ \\
\hline 1995 & 611 & 93.8 & 11.303 & 0.947 & 797323 & 0.752 & 0.030 & 0.803 & $0.081^{* *}$ \\
\hline 2000 & 325 & 96.1 & 11.515 & 1.031 & 1554390 & 0.704 & 0.039 & 0.827 & $0.074^{* *}$ \\
\hline 2005 & 267 & 96.4 & 11.742 & 1.081 & 2113786 & 0.715 & 0.044 & 0.839 & $0.064^{* * *}$ \\
\hline 2010 & 180 & 97.2 & 11.910 & 1.078 & 2994218 & 0.670 & 0.050 & 0.856 & $0.071^{* * *}$ \\
\hline \multicolumn{10}{|c|}{ B. All commercial banks - including off balance sheet items } \\
\hline 1990 & 532 & 95.7 & 11.186 & 0.989 & 947071 & 0.754 & 0.032 & 0.763 & $0.073^{* *}$ \\
\hline 1995 & 655 & 93.4 & 11.301 & 0.941 & 748830 & 0.734 & 0.029 & 0.830 & $0.083^{* *}$ \\
\hline 2000 & 451 & 94.5 & 11.484 & 0.991 & 1062852 & 0.705 & 0.033 & 0.873 & $0.075^{* *}$ \\
\hline 2005 & 354 & 95.3 & 11.727 & 1.054 & 1586894 & 0.710 & 0.038 & 0.905 & $0.066^{* * *}$ \\
\hline 2010 & 183 & 97.2 & 11.924 & 1.082 & 3052227 & 0.645 & 0.048 & 0.917 & $0.072^{* *}$ \\
\hline \multicolumn{10}{|c|}{ C. Ownership groups: BHC and independent commercial banks } \\
\hline 1980 & 728 & 94.1 & 10.820 & 0.901 & 425544 & 0.773 & 0.029 & 0.788 & $0.075^{* *}$ \\
\hline 1985 & 504 & 95.5 & 10.977 & 0.937 & 638739 & 0.684 & 0.030 & 0.818 & $0.074^{* *}$ \\
\hline 1990 & 356 & 96.2 & 11.122 & 0.972 & 950579 & 0.663 & 0.035 & 0.835 & $0.077^{* *}$ \\
\hline 1995 & 283 & 96.3 & 11.312 & 0.984 & 1148926 & 0.656 & 0.039 & 0.874 & $0.079^{* *}$ \\
\hline 2000 & 260 & 96.1 & 11.534 & 1.036 & 1547326 & 0.694 & 0.043 & 0.868 & $0.070^{* * *}$ \\
\hline 2005 & 220 & 96.5 & 11.773 & 1.098 & 2290864 & 0.700 & 0.047 & 0.865 & $0.063^{* *}$ \\
\hline 2010 & 170 & 97.1 & 11.954 & 1.087 & 2994218 & 0.685 & 0.053 & 0.868 & $0.067^{* *}$ \\
\hline
\end{tabular}

D. Ownership groups: BHC and independent commercial banks - including off balance sheet items

$\begin{array}{llllllllll}1990 & 368 & 96.1 & 11.124 & 0.971 & 939046 & 0.658 & 0.034 & 0.832 & 0.078^{* * *} \\ 1995 & 287 & 96.3 & 11.319 & 0.986 & 1159706 & 0.645 & 0.038 & 0.853 & 0.080^{* *} \\ 2000 & 260 & 96.1 & 11.545 & 1.041 & 1596308 & 0.677 & 0.042 & 0.880 & 0.071^{* *} \\ 2005 & 214 & 96.6 & 11.793 & 1.110 & 2498682 & 0.668 & 0.046 & 0.905 & 0.065^{* *} \\ 2010 & 172 & 97.0 & 11.968 & 1.092 & 3021667 & 0.652 & 0.050 & 0.922 & 0.068^{* *}\end{array}$

Notes to Table 2

Results reported in Panels A and C are for balance-sheet assets. Results reported in Panels B and D are for the sum of balance-sheet assets and OBS credit equivalents, calculated in accordance with the method described by Janicki and Prescott (2006, pp 312-4).

$\mathrm{k}$ (value) is the fitted threshold rank, below which the log size distribution is truncated normal, and above which the size distribution is Pareto. $\mathrm{k}$ (percentile) is $\mathrm{k}$ (value) expressed as a percentile of the entire size distribution.

$\mu_{\mathrm{k}}$ and $\sigma_{\mathrm{k}}$ are the mean and standard deviation of the fitted truncated normal distribution for log size (asset size measured in USD thousands, 2010 prices, conversion using IMF US GDP deflator).

$\Theta_{\mathrm{k}}$ is the fitted threshold asset size (measured in USD thousands).

$\alpha_{k}$ and $s\left(\alpha_{k}\right)$ are the fitted upper-tail shape parameter in the Pareto distribution, and the standard error of this fitted parameter.

$\mathrm{CR}_{\mathrm{k}}$ is the $\mathrm{k}$-firm concentration ratio ( $\mathrm{k}$ defined as above).

$\mathrm{K}-\mathrm{S}$ is the Kolmogorov-Smirnov test of the null hypothesis that the entire log size distribution is normal.

${ }^{* *}$ denotes rejection of the null at the 0.01 level; ${ }^{*}$ denotes rejection at the 0.05 level. 
Table 3 Summary estimation results: Commercial banks, alternative size measures

\begin{tabular}{|c|c|c|c|c|c|c|c|c|c|}
\hline & & Loans & & & eposit. & & & ploye & \\
\hline & $\begin{array}{l}\mathrm{k}(\mathrm{v} \\
\text { perce }\end{array}$ & & $\alpha_{k}$ & $\begin{array}{l}\mathrm{k}(\mathrm{v} \\
\text { perce }\end{array}$ & & $\alpha_{k}$ & $\begin{array}{l}\mathrm{k}(\mathrm{v} \\
\text { perce }\end{array}$ & & $\alpha_{k}$ \\
\hline All comr & ial ba & & & & & & & & \\
\hline 1980 & 526 & 96.4 & 0.898 & 572 & 96.0 & 0.934 & 573 & 96.0 & 0.927 \\
\hline 1985 & 534 & 96.3 & 0.822 & 568 & 96.0 & 0.880 & 690 & 95.2 & 0.877 \\
\hline 1990 & 573 & 95.3 & 0.768 & 523 & 95.7 & 0.809 & 588 & 95.2 & 0.824 \\
\hline 1995 & 565 & 94.3 & 0.728 & 614 & 93.8 & 0.805 & 398 & 96.0 & 0.806 \\
\hline 2000 & 341 & 95.9 & 0.714 & 311 & 96.2 & 0.754 & 325 & 96.1 & 0.770 \\
\hline 2005 & 217 & 97.1 & 0.724 & 224 & 97.0 & 0.742 & 266 & 96.4 & 0.789 \\
\hline 2010 & 190 & 97.1 & 0.723 & 185 & 97.1 & 0.712 & 199 & 96.9 & 0.800 \\
\hline Owner & 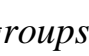 & 100 & . & t comn & . 1 & & & & \\
\hline 1980 & 615 & 95.0 & 0.760 & 723 & 94.2 & 0.768 & 529 & 95.7 & 0.788 \\
\hline 1985 & 625 & 94.4 & 0.698 & 601 & 94.6 & 0.705 & 547 & 95.1 & 0.722 \\
\hline 1990 & 398 & 95.8 & 0.678 & 520 & 94.5 & 0.701 & 529 & 94.4 & 0.739 \\
\hline 1995 & 390 & 94.9 & 0.681 & 267 & 96.5 & 0.649 & 264 & 96.6 & 0.691 \\
\hline 2000 & 247 & 96.3 & 0.691 & 265 & 96.0 & 0.691 & 186 & 97.2 & 0.695 \\
\hline 2005 & 195 & 96.9 & 0.718 & 201 & 96.8 & 0.697 & 192 & 97.0 & 0.771 \\
\hline 2010 & 173 & 97.0 & 0.737 & 182 & 96.9 & 0.713 & 130 & 97.8 & 0.752 \\
\hline
\end{tabular}

Notes to Table 3

$\mathrm{k}$ (value) is the fitted threshold rank, below which the log size distribution is truncated normal, and above which the size distribution is Pareto. $\mathrm{k}$ (percentile) is $\mathrm{k}$ (value) expressed as a percentile of the entire size distribution. $\alpha_{k}$ is the fitted upper-tail shape parameter in the Pareto distribution. 
Table $4 \quad$ Estimation results: Credit unions, assets size measure

\begin{tabular}{|c|c|c|c|c|c|c|c|c|c|}
\hline \multicolumn{10}{|c|}{ All credit unions } \\
\hline 1995 & 11746 & 36132 & 0.061 & 0.088 & .124 & 19.2 & .830 & 1.822 & 0.007 \\
\hline 2000 & 103 & 53866 & 0.067 & 0.096 & 0.138 & 21.9 & 9.141 & 878 & 0.008 \\
\hline 2005 & 86 & 88071 & 0.085 & 0.119 & 0.165 & 31.4 & 9.519 & 1.939 & $0.016^{*}$ \\
\hline 2010 & 7334 & 124611 & 0.108 & 0.143 & 0.191 & 46.5 & 9.780 & 2.004 & $0.018^{*}$ \\
\hline
\end{tabular}

Notes to Table 4

$\mu_{0}$ and $\sigma_{0}$ are the mean and standard deviation of the fitted normal distribution for log size (asset size measured in USD thousands, 2010 prices, conversion using IMF US GDP deflator).

$\mathrm{K}-\mathrm{S}$ is the Kolmogorov-Smirnov test of the null hypothesis that the entire log size distribution is normal.

${ }^{* *}$ denotes rejection of the null at the 0.01 level; ${ }^{*}$ denotes rejection at the 0.05 level. 
Figure 1 Estimation results, upper-tail threshold rank k

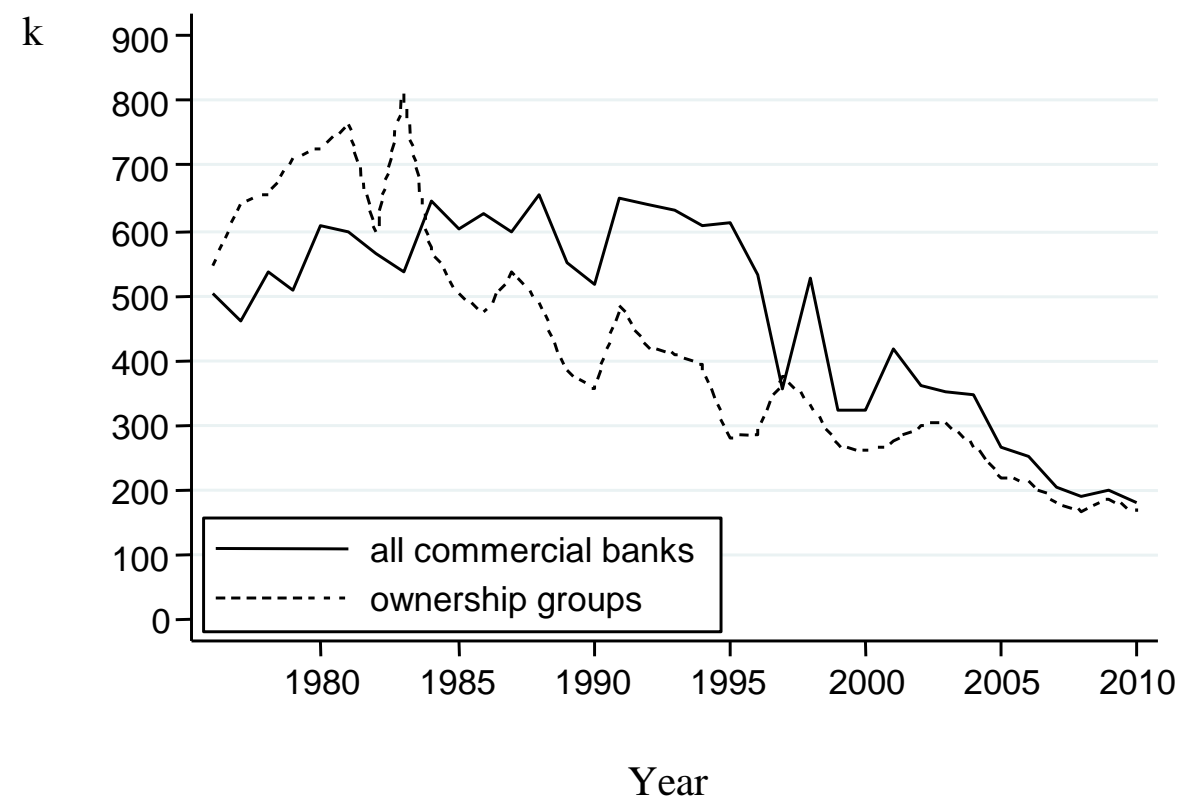


Figure 2 Estimation results, upper-tail shape parameter $\alpha_{k}$

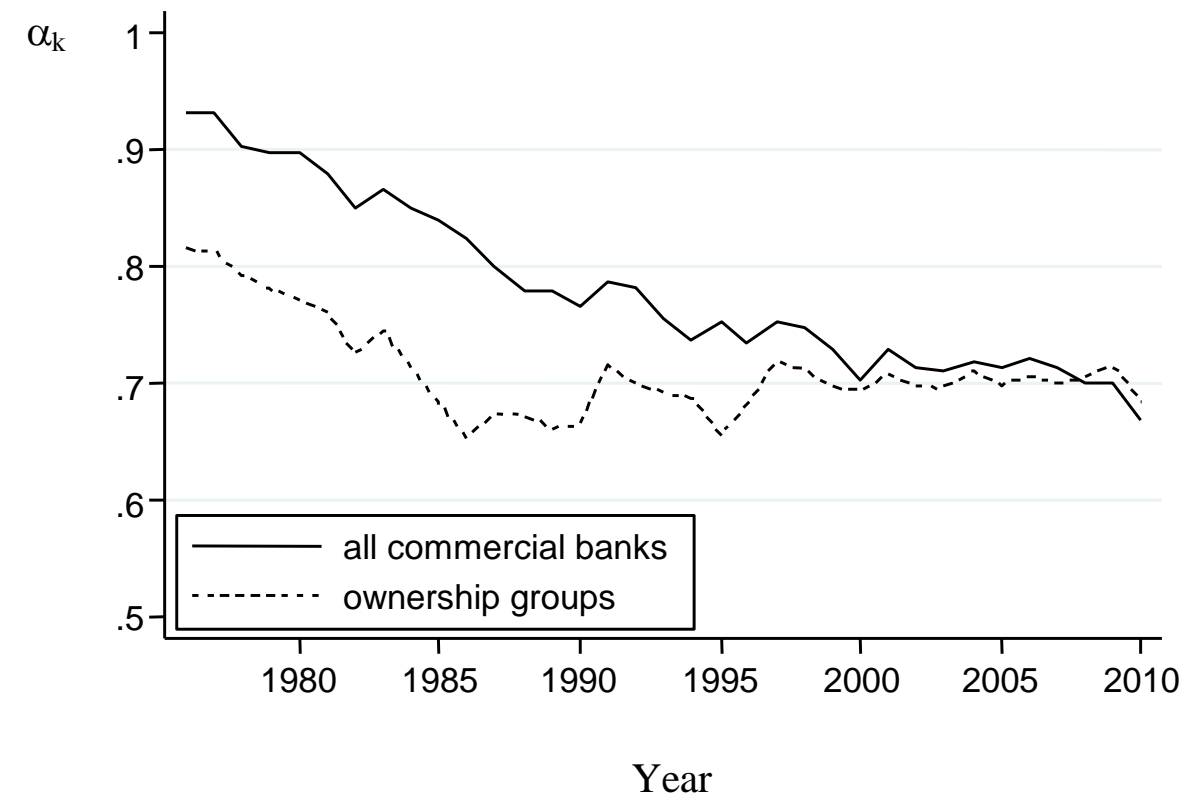




Figure 4 Rank-size plot, assets size measure, credit unions, 2010

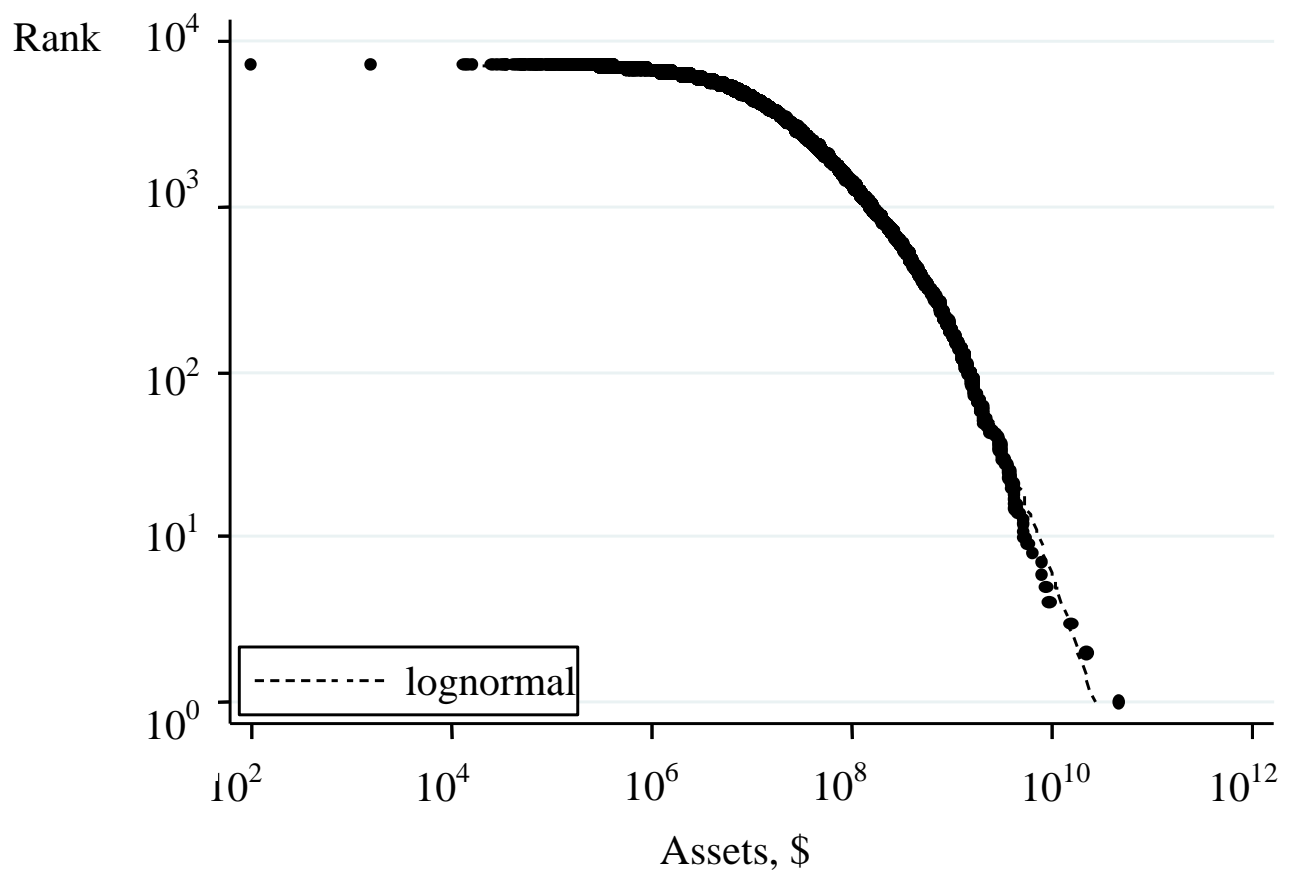

